\title{
Law $\mathbf{k}$ Social Inquiry
}

\section{Journal of the American Bar Foundation \\ Volume 23, Number 1, Winter 1998}

The University of Chicago Press 


\section{Law \&}

\section{Social Inquiry}

Journal of the American Bar Foundation

Published by The University of Chicago Press

$\begin{array}{ll}\text { Editors } & \text { Carol A. Heimer } \\ & \begin{array}{l}\text { Elizabeth Mertz } \\ \text { Victoria Saker Woeste }\end{array} \\ \text { Review Editor } & \text { Howard S. Erlanger } \\ \text { Associate Editors } & \text { John L. Comaroff } \\ & \text { Austan Goolsbee } \\ & \text { Karyl A. Kinsey } \\ \text { Managing Editor } & \text { John Atkinson } \\ \text { Editorial Coordinator } & \text { Rozanne Caldwell } \\ \text { Manuscript Editors } & \text { Barbara J. Hofmaier } \\ & \text { Susan F. Messer }\end{array}$

\section{Editorial Board}

Richard L. Abel, Professor of Law, University of California, Los Angeles Ian Ayres, Professor of Law, Yale University

Donald Black, Professor of Sociology, University of Virginia

Erhard Blankenburg, Professor of Sociology of Law, Free University of Amsterdam John Braithwaite, Professor of Law and Sociology, The Australian National University Jane F. Collier, Professor of Anthropology, Stanford University

Phoebe C. Ellsworth, Professor of Law and Psychology, University of Michigan

Eliot L. Freidson, Professor of Sociology, New York University

Lawrence M. Friedman, Professor of Law, Stanford University

Hazel Genn, Professor of Law, Queen Mary and Westfield College, University of London

Carol J. Greenhouse, Professor of Anthropology, Indiana University

Valerie P. Hans, Professor of Criminal Justice, University of Delaware

Earl Johnson, Jr., Associate Justice, California State Court of Appeal

Doreen McBarnet, Senior Research Fellow, Centre for Socio-Legal Studies, Wolfson College, Oxford

Carrie J. Menkel-Meadow, Professor of Law, University of California, Los Angeles

Laura Nader, Professor of Anthropology, University of California-Berkeley

Judith Resnik, Professor of Law, Yale University

Daniel Rubinfeld, Professor of Economics, University of California-Berkeley

Dietrich Rueschemeyer, Professor of Sociology, Brown University

Martin M. Shapiro, Professor of Law, University of California-Berkeley

Peter Siegelman, Ph.D., Economist

Susan S. Silbey, Professor of Sociology, Wellesley College

David Sugarman, School of Law, Lancaster University

David M. Trubek, Professor of Law, University of Wisconsin

Barbara Yngvesson, Professor of Anthropology, Hampshire College

Michael Zander, Professor of Law, Department of Law, London School of Economics 


\section{Law \& \\ Social Inquiry}

Volume 23, Number 1, Winter 1998

\section{ARTICLES}

Not Ozzie and Harriet: Postwar Divorce and the American Liberal

Welfare State

Katherine L. Caldwell

Legitimacies, Indian Identities, and the Law: The Politics of Sex and the Creation of History in Colonial New England

Ann Marie Plane

\section{REVIEW ESSAYS}

Power in Paradise: The Political Implications of Santos's Utopia

Eve Darian-Smith

Commentary

Oppositional Postmodernism and Globalizations

Boaventura de Sousa Santos

Derrick Bell's Re-Sounding: W.E.B. Du Bois, Modernism, and

Critical Race Scholarship

James R. Hackney Jr.

Business Myths, Lawyerly Strategies, and Social Context: Ernst on Labor Law History

Andrew Wender Cohen

From Fundamental Law to Constitutional Politics-And Back

Howard Gillman

Up from the Streets: Handler and the Ambiguities of Empowerment and Dependency

Julie A. White and John Gilliom

Commentary

Living with Ambiguity

Joel Handler 


\section{Publication Policy}

The American Bar Foundation is an independent research institute committed to socio-legal research. Consistent with its mandate to create and disseminate knowledge about law, the legal profession, and legal institutions, Law and Social Inquiry: Journal of the American Bar Foundation invites the submission of articles that make original contributions to understanding of sociolegal processes. Law and Social Inquiry publishes both empirical and theoretical studies from a variety of disciplinary perspectives. The analyses, conclusions, and opinions are those of the authors alone.

Manuscript Evaluation: Law and Social Inquiry is a refereed journal. Manuscripts that the Editors deem appropriate for the journal are evaluated by two or more reviewers with expertise in the relevant subject matter and methodology. Manuscripts produced by $A B F$ research fellows are evaluated by the same process as outside manuscripts and are not accorded priority in publication.

Submission of Manuscripts: Law and Social Inquiry uses the author/date citation system, as described in The Chicago Manual of Style, 14th Edition. You may obtain our style guidelines via surface mail by writing to us at: Editorial Coordinator, Law and Social Inquiry, American Bar Foundation, 750 N. Lake Shore Drive, Chicago, Illinois 60611; or from our Web site at: http://www.journals.uchicago.edu/LSI/. Manuscripts submitted to Law and Social Inquiry should be typed double-spaced and be accompanied by an abstract of not more than 150 words. The review process is anonymous; all identifying information should appear only on a separate cover sheet and not in the body of the manuscript.

Law and Social Inquiry does not accept multiply submitted articles. The Editors endeavor to make decisions promptly, usually about two months after submission.

Editing of Manuscripts: All manuscripts accepted for publication are edited for style by professional copy editors in consultation with the author. Copy editors do not check citations. Authors see edited manuscripts and/or proofs.

Off-Prints to Authors: Without charge, we provide authors with 25 off-prints of their articles, essays, or exchanges (but not symposia) that appear in Law and Social Inquiry. Additional off-prints may be ordered at the author's expense. Authors receive 1 copy of the issue in which their contributions appear.

Republication Rights: The Foundation normally permits authors to republish their manuscripts in books or use their manuscripts after publication, but Law and Social Inquiry has the right to first publication of edited manuscripts. The journal retains the right to republish manuscripts as reprints or as part of any reproduction of the issue or volume in which they appear, by any means, including without limit electronic means or microfilm.

Copying Beyond Fair Use: The code on the first page of a contribution in this journal indicates the copyright owner's consent that copies of the contribution may be made beyond those permitted by Sections 107 or 108 of the U.S. Copyright Law provided that copies are made only for personal or internal use, or for the personal or internal use of specific clients and provided that the copier pay the stated percopy fee through the Copyright Clearance Center, Inc., 222 Rosewood Drive, Danvers, MA 01923. To request permission for other kinds of copying, such as copying for classroom use without charge, copying for general distribution, for advertising or promotional purposes, for creating new collective works, or for resale, kindly write to the Permissions Department, University of Chicago Press, 5801 S. Ellis Avenue, Chicago, IL 60637. 
Comments and Responses: Comments on or responses to articles or review essays in the form of brief, scholarly statements will be published at the discretion of the Editors or Review Section Editor.

Send article manuscripts to:

The Editors

Law and Social Inquiry

American Bar Foundation

750 N. Lake Shore Drive

Chicago, IL 60611

(312) $988-6500$
Send inquiries regarding review essays to:

Howard S. Erlanger

Review Editor

Law and Social Inquiry

Institute for Legal Studies

Law School

University of Wisconsin

Madison, WI 53706

(608) 263-7405

For further information via the Internet-

Web site: http://www.journals.uchicago.edu/LSI/

E-mail: 1si-abf@abfn.org

Law and Social Inquiry is available for full-text search on the LEXISTM/

NEXISTM $^{\text {TM }}$ and WESTLAWTM ${ }^{\mathrm{TM}}$ on-line services.

\section{Annual U.S. subscription rates:}

$\begin{array}{llrr} & 1 \mathrm{yr} . & 2 \mathrm{yr} . & 3 \mathrm{yr} . \\ \text { Individuals } & \$ 36 & \$ 66.25 & \$ 91.80 \\ \text { Academic } & \$ 29 & \$ 53.35 & \$ 73.95 \\ \text { Institutions } & \$ 59 & \$ 108.55 & \$ 150.45\end{array}$

Outside U.S. please add a postage charge of $\$ 6.00$ per year to the U.S. rates. Canadians please add 7\% GST tax to above rates as follows: Oneyear rates: Individuals \$2.52; Academic \$2.03; Institutions \$4.13. Twoyear rates: Individuals $\$ 4.64$; Academic $\$ 3.73$; Institutions $\$ 7.60$. Threeyear rates: Individuals $\$ 6.43$; Academic $\$ 5.18$; Institutions $\$ 10.53$.

Single copies: $\$ 14.75$ for institutions, $\$ 9.00$ for individuals. Checks should be made payable to Law $\mathcal{E}$ Social Inquiry, University of Chicago Press, Journals Division, P.O. Box 37005, Chicago, Illinois 60637. (Fax: 773-7530811; E-mail: subscriptions@journals.uchicago.edu) Volumes 1-12 available from Fred B. Rothman \& Company, 10368 West Centennial Road, Littleton, Colorado 80127. (303) 979-5657

Volumes available in microfilm from University Microfilms International, 300 North Zeeb Road, Ann Arbor, Michigan 48106.

(C) 1998 American Bar Foundation. All rights reserved.

Law and Social Inquiry: Journal of the American Bar Foundation (ISSN: 0897-6546) is published quarterly-winter, spring, summer, and fall-by The University of Chicago Press, 5720 South Woodlawn Ave., Chicago, Illinois 60637. Subscription agent for Japan: Kinokuniya Company, Ltd. Periodicals postage paid at Chicago, Illinois and at additional mailing office.

POSTMASTER: Send address changes to: Law and Social Inquiry, P.O. Box 37005, Chicago, IL 60637. 